\title{
TRANSLATION OF SAPARDI DJOKO DAMONO'S POEM INTO ENGLISH
}

\author{
Ary Fadjar Isdiati \\ English Education Department \\ STKIP Panca Sakti Bekasi, Indonesia \\ aryisdiati16@gmail.com
}

\begin{abstract}
This article investigates the strategies John H. McGlynn used in translating Sapardi Djoko Damono's poem Sajak Orang Gila into English entitled Ballad of a Crazy Man. Has this translation's poem equivalence in the word level? If not, what is the cause? This study uses is a qualitative approach in describing the data. The data are all stanzas and lines taken from the poem Sajak Orang Gila and Ballad of a Crazy Man. Words, phrases, and sentences in all the stanzas and lines were analyzed using the poetry translation theory by Andre Lefevere to classify what strategies translator used in translating the poem as well as the Mona Baker's theory in identifying the cause of inequality. The analysis shows that John H. McGlynn applied literal and interpretation strategies. The former strategy was used to translate 11 stanzas, and the latter one was used for 2 stanzas. In conclusion, the translation of Sajak Orang Gila is good as the meaning has been successfully conveyed in Ballad of a Crazy Man. However, the translation of some stanzas was found to be mismatched the meanings in words. The differences in physical or interpersonal perspectives, the target language lacks a special term (hyponym), and differences in expressive meanings are the sources of inequivalence in meanings.
\end{abstract}

Keywords: translation strategy; poem; equivalence, literal and interpretation strategies

\section{INTRODUCTION}

In addition to translating language, in the translation process the translator must also to translate the cultural content in the text. Therefore, the translator's ability to understand the contents of the text and cultural content is highly demanded, so it can be said that the translator is a figure that cannot be underestimated.

Compared to other literary genres, poem can be considered the most difficult to translate, because translators not only transfer meaning but also pay attention to the beauty of its form. Therefore, the translation of poem is relatively small and growth is slow compared to other literary genres, especially novels.

Translating poem is a work rarely done by a translator. Not only because in translating the poem the translator must reexpress the beauty of the original poetic text, but also because he has to re-express the meaning contained in the poem into the poem text of the target language. So, some people think, translating poem is impossible because it is considered to replace the whole beauty of the original poetic text. Even some experts argue that the translation of poem in essence cannot be done. Frost (1969) says that the main characteristic of poetic discourse that distinguishes it from general discourse is that the form and content of poetry cannot be separated. The form and content of the poem are interrelated and make the translation of poetry more difficult than other types of translations. The opponents of poetic translation such as Bateson and Turco in Lazim propose their reasons: when poems, especially philosophical ones, satires, lyrics, etc. are translated into another language, they become not only flabby poems, but rather new ones in a new language. They stress that poetry in translation surely loses its basic elements. Such views go with the belief that poetry is wholly lost in translation. Also expressed by Venuti (2004) that translating 
of poetry often cannot reproduce both form and content in their translations, because in general forms are usually sacrificed for the sake of content. Poem has its own aesthetic value (Sari, 2015) that cannot be found in other literary works such as novels or short stories. Poem has rhythm, rhyme, word pressure (meter), tone, and structure that may be different from similar elements in daily language. The poem's translator must pay attention to the elements forming poem, namely rhyme, typography, concrete words, imagination, speech, diction, themes, feelings, tone and atmosphere, and mandate (Kosasih, 2008). It is natural that Newmark (1988) states that the translation of poem is the most difficult type.

The research that underlies this research was conducted by Agung Prasetyo (2016) with the title Penerapan Metode Penerjemahan Interpretasi Puisi oleh Susan Bassnett aimed at discussing the application of poem translation methods that emphasize the meaning of poem. Data is poem with the title Geneva Bulan Juli by Toeti Heraty as source poem and translated with the title Geneva in July as target poem, translated by Ulrich Kratz (Anggana, 2012). The results were found the most widely used interpretation strategies, then literal translation strategies, and rhyme translation strategies.

\section{Translation's Method of Poem}

Many translation methods, techniques, or strategies can be used to translate texts. But not all of the translation methods, techniques, or strategies are suitable using in translating poetry. According to Lefevere (1975) there are seven translation strategies that can be used to translate poem, namely: (1) phonemic translation, which is a translation strategy that tries to recreate the sound of source poem into target poem or create the same sound between source poem and target poem, and at the same time convey mean. This type of translation usually results in rigid translation and sometimes omits some of the original meaning; (2) literal translation is a literal translation strategy, which emphasizes word for word translation. The use of this strategy will not be able to move the original meaning in source language, because the phrases and sentence structure tend to be different from target language; (3) metric translation is a translation strategy that emphasizes that target poem has the same metrics as source poem. Whereas we know that each language has its own pronunciation and spelling system, so the use of this strategy will result in translations that are not appropriate in meaning and structure; (4) translation of stanzas into prose is a translation strategy by changing the structure of poetic text into the form of prose text structure. This type of translation strategy will eliminate the beauty of the original poetic form; (5) rhyme translation is a translation strategy that emphasizes the transfer of rhymes of source poem to target poem. The results of the translation will be physically appropriate but tend not to have the same meaning; (6) version translation is a translation strategy by changing the form of source poem into another form as target poem. The use of this strategy tends to ignore the rhymes and metrics of the original poem so that the results of the translation will be physically different, but the meaning of the source poem and target poem is same, and (7) interpretation translation, namely the translation strategy by reproducing and interpreting the structure of source poem into target poem by maintaining the composition and topic of source poem (Bassnet, 2002).

It was further said that phonemic translation, literal translation, and rhyme translation emphasized the poetic form or structure of a poem, while the translation of poem into prose, version translation, and interpretation translation emphasized the meaning of source poem which would 
be transferred to target poem. The whole strategy only emphasizes on one or several poetic components. Whereas poem has a single element. If one element is not interconnected with other elements, the meaning of the results of the translation of poem as a whole will be damaged.

\section{Equality in Word Level}

Basically, equivalence is a basic concept in translation theory, because in the translation process the translator must look for the equivalent meaning between the source text and the target text. The equivalence in the target text is expected to be able to communicate the meaning or message contained or referred to in the source text.

In the translation process, usually, the translator will start by encoding the units and structures that exist in the source text into the target text. The first unit to be analyzed is the word as stated by Newmark (1988) that there are only words also known as lexicon (Ramli, 2019) on source text to be translated. From this statement, we can assume that in the process of translation we must first understand in understanding the source text as a whole is the word.

Many people assume that words are the smallest units that has meaning. But in linguistics, the smallest unit that has meaning is morpheme. This was revealed by Hatch and Brown in Nababan (2003) "morphemes are the smallest units that have meaning that cannot be broken down into smaller units". Thus, it can be concluded that morpheme has only one element of meaning while words can have more than one element of meaning. Therefore, in the process of translation it is possible to have an element of meaning symbolized by one word in a particular language, but it must be symbolized by several words in another language, or vice versa. Example: the word tennis player in
English is the equivalent of one word in Turkish, namely tenisci; instead the type word in English is symbolized by three words in Spanish, namely the market a maquina.

From the example above, we can conclude that not always one word in the source text is translated with one word also in the target text, or vice versa. Therefore, to determine an appropriate equivalence, in analyzing a translator's words it is necessary to apply structural analysis or morphemic analysis on the surface structure, while in the inner structure by applying the analysis of the meaning components (Nababan, 2003). However, because translations involve two different languages, words often do not have an equivalence, often called nonequivalence cases or empty equivalents.

\section{Inequality Problem}

The problem of incompatibility at the word level, namely that the target language does not have a direct equivalence to a word in the source language, the type and degree of difficulty caused by this case vary greatly depending on the nature of the incompatibility itself. Therefore, a type of inequality that arises requires a specific strategy to overcome the problem.

Catford (1974) states that linguistics and non-linguistics/cultural untranslatability factors cause the weakness of translation. Baker (1992) also states that the causes of this case are:

1. Culture specific

Words in the source language related to the local culture can express a unique concept that is not recognized in the target culture. Example in Javanese words tingkeban, nyewu, mitoni

2. The source language is not lexicalized in the target language. 
The concept of source language can be understood with the target language, but the target language does not have the appropriate words to describe the concept. For example, Indonesian people, especially in urban areas are familiar with pizza food, but we don't have the word to express the concepts contained in it.

3. The source language words are semantically complex.

Semantic words in the target language may be very complex. Sometimes a word can express a more complex meaning than the meaning of a sentence. For example, a Javanese word matun which means the work done by farmers in the fields, such as cleaning weeds that disturb their rice plants. That's why to be able to deduce a very complex meaning is usually effective by nominalization. The use of nominalization is often used by scientists, such as words: reboisasi, abrasi, sedimentasi and others.

4. The source and target language make different distinctions in meaning.

For example, the Indonesian language distinguishes the concepts of kehujanan and hujan-hujanan. Kehujanan means that we do not mean to go out to bathe in the rain. While the hujan-hujanan is a deliberate condition. English does not distinguish the two of them. Therefore, we will have difficulty translating the sentence "He is going out in the rain" into Indonesian if the context of the sentence is not clear.

5. The target language lacks of super ordinate.

The target language does not have a superior element that points to an object or concept. For example, English has an element of superior facilities that refers to subordinate elements such as buildings, natural equipment, and services for certain activities. Whereas Russian language does not have an element of superior like that.

6. The target language lacks a special term (hyponym).

The target language has no subordinate/hyponym elements. In English, the word is classified as a superior element which has several subordinate elements such as repeat, review, and report. The word house has several subordinate elements such as bungalows, cottages, mansions, halls, villas, hut, and lodge.

7. Differences in physical or interpersonal perspectives.

Physical perspective shows the relationship of people in a discourse. For example, in Javanese the word pulang depends on who and the position of the person in the discourse, so we must choose the right words that are manthuk, mulih, wangsul, or kondur.

8. Differences in expressive meaning.

The word in source language and target language have the same proposition meanings but differ in the expressive meaning they contain. Examples of the words be quiet and shut up have the same proportion meaning that the speaker tells the other person not to speak. However, the expressive meaning of these words is very different.

9. Differences in frequency and purpose of using specific forms.

Often words in the target language do not have direct guidelines in the target language due to differences in word formation. For example, English has pairs of words that have the same tone as the interviewer/interview, so does Indonesian penatarl petatar. But the derivation of certain words can also produce different patterns of word formation. For example, the suffix -ity in the unity and nationality can be translated with the pattern of ness, namely unity, and nationality, but the 
pattern cannot be used in the word loyalty.

10. Differences in frequency and purpose of using specific forms.

In English the form $\mathrm{V}+$ ing is very often used to combine two ideas in a clause, but not so in German and Indonesian. Therefore, it can be said that this $\mathrm{V}+$ ing form is a feature of the English writing style, and if we omit it means we have eliminated the natural style of the English text.

11. Use of the word loan in the source text. When a foreign word is used in a language, the meaning of the foreign word is unpredictable. For example, the word feminist in English means a person who supports the belief that women should have the same rights and opportunities as men. Whereas in Japanese means a man who is excessively soft with women.

Based on the above discussion, this research investigates the strategies John $\mathrm{H}$. McGlynn used in translating Sapardi Djoko Damono's poem Sajak Orang Gila into English entitled Ballad of a Crazy Man.

\section{METHODOLOGY}

It is a descriptive qualitative study. The data sources are the poem Sajak Orang Gila by Sapardi Djoko Damono and its translation Ballad of a Crazy Man by John H. McGlynn. The poem Sajak Orang Gila and its translation in English Ballad of a Crazy Man consist of 6 parts; in parts I, II, III, IV, and V each consists of two stanzas. Whereas, section VI consists of 3 stanzas. The poem overall has 13 stanzas. The total of lines in each stanza varies. The analyzed units are words, expressions, and sentences in all lines and verses of the poem. The steps taken by the author include: 1 ) perusing the poem in the source language to find out the meaning, understanding, and story in the poem; 2) reading poem in the target language carefully to find out the meaning, understanding, and story in the poem; 3 ) comparing poem in the source language and in the target language, and determining the translation strategy used to translate the poem; 4) draw conclusions whether poem in the target language has meaning, understanding, and a story that is commensurate with poem in the source language. If it lacks or has no equivalent meaning, what is the cause?

\section{RESULTS AND DISCUSSION}

Below are data of poem Sajak Orang Gila by Sapardi Djoko Damono and its translation in English Ballad of a Crazy Man by John H. McGlynn.

\section{Sajak Orang Gila}

\section{I}

aku bukan orang gila, saudara tapi anak-anak kecil mengejek orang-orang tertawa

$$
\begin{gathered}
\text { ketika kukatakan kepada mereka: aku } \\
\text { temanmu } \\
\text { beberapa anak berlari ketakutan } \\
\text { yang lain tiba melempari batu }
\end{gathered}
$$

\section{II}

aku menangis di bawah trembesi di atas dahan kudengar seekor burung bernyanyi

anak-anak berkata: lucu benar orang gila itu

sehari muput menangis tersedu-sedu

orang-orang yang lewat di jalan berkata pelan: orang itu sudah jadi gila sebab terlalu berat menafsir makna dunia

\section{III}

sekarang kususuri saja sepanjang jalan raya

sambil bernyanyi: aku bukan orang gila

lewat pintu serta lewat jendela 
nampak orang-orang yang menggelengkan kepala mereka:

kasihan orang yang dulu terlampau sabar itu roda berputar dan dia jadi begitu.

\section{IV}

kupukul tong sampah dan tiang listrik kunyanyikan lagu tentang lapar yang menarik

kalau hari ini aku tak makan lagi jadi genap sudah berpuasa dalam tiga hari

tapi pasar sudah sepi, sayang sekali tak ada lagi yang memberikan nasi ke mana aku mesti pergi, ke mana lagi

\section{V}

orang itu sudah lama gila, kata mereka tapi hari ini begitu pucat nampaknya apa kiranya yang telah terjadi padanya

aku katakan pada mereka: aku tidak gila! aku orang lapar, saudara.

\section{VI}

ku dengar berkata seorang ibu: jangan kalian ganggu orang gila itu, anakku

nanti kalian semua diburu

orang kota semua telah mengada-ada, aduhai

menuduhku seorang yang sudah gila

aku toh cuma menangis tanpa alasan

tertawa-tawa sepanjang jalan

dan lewat jendela, tergeleng kepala mereka:

kurus benar sejak ia jadi gila.

Yogyakarta, '61

(Sastra, Th. 1 No. 7, November 1961)

\section{Ballad of a Crazy Man}

\section{I}

I am not crazy, my friend but children mock me and people laugh

when I say to them, I am your friend some of the children run away in fear while other throw stones

\section{II}

I cry beneath a shade tree above, I hear a bird sing

the children say: that crazy man is really funny

all he does is cry and sob the whole day

people passing by on the street mutter: that man is crazy from trying too hard to understand the meaning of the world

\section{III}

now I wander along the size of the road while singing: I am not crazy

in the doorways and windows I pass

I see people shaking their heads with pity for that man who was once so self possessed

but the wheels turned, and now he's like that

\section{IV}

I bang a garbage can, electric poles

I sing pop songs about hunger if today I don't eat again

it will be three straight days I've fasted

but the market is quiet, which is too bad no one is there to offer me rice where is it that I must go, where must I go now

\section{V}

that man's been crazy for quite a while, they say

but today he seems particularly pale what could have happened to him

I say to them: I am not crazy! I am hungry, my friend

\section{VI}


I hear a woman say to her children: you leave that crazy man alone or one day he'll come after all of you

and in windows, people shake their heads he's awfully thin since becoming crazy

city people make up things, utterly fantastic

accusing me of being a crazy man but I am only crying for no reason and laughing as I walk the roads

Based on Andre Lavafere's translation strategy, the translation strategies used to translate poem Sajak Orang Gila into English Ballad of a Crazy Man are as follows:

Table 1. Translation Method Poem of Sajak Orang Gila Into Ballad of a Crazy Man

\begin{tabular}{|l|l|l|l|l|l|l|l|l|l|l|l|l|l|c|}
\hline \multicolumn{1}{|r|}{ Stanza } & $\mathbf{1}$ & $\mathbf{2}$ & $\mathbf{3}$ & $\mathbf{4}$ & $\mathbf{5}$ & $\mathbf{6}$ & $\mathbf{7}$ & $\mathbf{8}$ & $\mathbf{9}$ & $\mathbf{1 0}$ & $\mathbf{1 1}$ & $\mathbf{1 2}$ & $\mathbf{1 3}$ & Total \\
Method & & & & & & & & & & & & & & \\
\hline $\begin{array}{l}\text { Phonemic } \\
\text { Translation }\end{array}$ & & & & & & & & & & & & & & 11 \\
\hline $\begin{array}{l}\text { Literal } \\
\text { Translation }\end{array}$ & & & & & & & & & & & & & \\
\hline $\begin{array}{l}\text { Metrical } \\
\text { Translation }\end{array}$ & & & & & & & & & & & & & & \\
\hline $\begin{array}{l}\text { Prose } \\
\text { Translation }\end{array}$ & & & & & & & & & & & & & \\
\hline $\begin{array}{l}\text { Rhymed } \\
\text { Translation }\end{array}$ \\
\hline $\begin{array}{l}\text { Blank Verse } \\
\text { Translation }\end{array}$ \\
\hline $\begin{array}{l}\text { Interpretation } \\
\text { Translation }\end{array}$
\end{tabular}

In the poem translation above, from 13 stanzas only 2 stanzas, stanza 6 and stanza 11, which are translated with interpretation translation strategy. The other 11 stanzas are translated with literal translation strategy. An explanation of the use of interpretation translation strategy and literal translation strategy in the process of translating poem above can be seen as follows:

Translation of stanza 6 and stanza 11 used interpretation translation strategy, namely translation strategy by reproducing and interpreting the structure of source poem into target poem by maintaining the composition and topic of source poem. It is clear in the table below that the translator tries to interpret the meaning of the source poem and convey it in the target poem using a different structure, but still maintains the structure and topic of the source poem. However, the meaning referred to in the source poem is conveyed in the target poem. 
Table 2. Translation of Stanza 6 and Stanza 11

\begin{tabular}{|c|c|c|c|}
\hline Source Text & $\begin{array}{l}\text { Total of } \\
\text { Words } \\
\end{array}$ & Target Text & $\begin{array}{l}\text { Total of } \\
\text { Words }\end{array}$ \\
\hline III & & III & \\
\hline lewat pintu serta lewat jendela & 5 & in the doorways and windows I pass & 7 \\
\hline $\begin{array}{c}\text { nampak orang-orang yang menggelengkan } \\
\text { kepala mereka: }\end{array}$ & 7 & I see people shaking their heads & 6 \\
\hline kasihan orang yang dulu terlampau sabar itu & 7 & $\begin{array}{l}\text { with pity for that man who was once so self } \\
\text { possessed }\end{array}$ & 11 \\
\hline roda berputar dan dia jadi begitu. & 6 & but the wheels turned, and now he's like that & 10 \\
\hline VI & & VI & \\
\hline ku dengar berkata seorang ibu: & 5 & I hear a woman say to her children: & 8 \\
\hline jangan kalian ganggu orang gila itu, anakku & 7 & you leave that crazy man alone & 6 \\
\hline nanti kalian semua diburu & 4 & or one day he'll come after all of you & 10 \\
\hline orang kota semua telah mengada-ada, aduhai & 7 & city people make up things, utterly fantastic & 7 \\
\hline menuduhku seorang yang sudah gila & 5 & accusing me of being a crazy man & 7 \\
\hline aku toh cuma menangis tanpa alasan & 6 & but I am only crying for no reason & 8 \\
\hline tertawa-tawa sepanjang jalan & 4 & and laughing as I walk the roads & 7 \\
\hline
\end{tabular}

Translation of stanza 1 until 5, stanza 7 until 10, stanza 12, and stanza 13 uses literal translation strategy, that emphasize word for word translation. Although literal translation emphasizes word-for-word translation, it does not mean that one word in the source text must be interpreted with one word in the target text, because it relates to the use of the word in the target language. Besides that, the English structure is different from the Indonesian structure. Therefore, there is a change in the number of words in the translation of each line.

a. The title in the source poem is 3 words, while in the target poem changes to 5 words.

b. In stanza 1, the first and second lines have different words. Only the third line did not change. In the source text 3 words and target text are also 3 words.

c. In stanza 2, all lines change.

d. In stanza 3 which consists of 4 lines, all of them also changes. e. In stanza 4 which consists of 3 lines, only the first line does not change. The next 2 lines change.

f. In stanza 5, the 2 lines show that the first line changes, while in the second line doesn't.

g. In stanza 7 there are 4 lines, the firstand fourth-lines change, while the second and third lines have the same words both in the source poem and the target poem

h. In stanza 8, all of the 3 lines change.

i. In stanza 9, the first line changes, while the second and third lines do not.

j. In stanza 10, there are 2 lines that all change.

k. In stanza 12 , from the 4 lines only the first line does not change. The next 3 lines change.

1. In stanza 13 consists of 2 lines that all change.

An explanation of the changes in total of words in the source and target poem above can be seen in table 2 below. 
Table 3. Change in Total of Words from the Source Poem to the Target Poem

\begin{tabular}{|c|c|c|c|}
\hline Source Text & $\begin{array}{l}\text { Total of } \\
\text { Words } \\
\end{array}$ & Target Text & $\begin{array}{l}\text { Total of } \\
\text { Words }\end{array}$ \\
\hline Sajak Orang Gila & 3 & Ballad of a Crazy Man & 5 \\
\hline $\mathbf{I}$ & & I & \\
\hline aku bukan orang gila, saudara & 5 & I am not crazy, my friend & 6 \\
\hline tapi anak-anak kecil mengejek & 5 & but children mock me & 4 \\
\hline orang-orang tertawa & 3 & and people laugh & 3 \\
\hline $\begin{array}{c}\text { ketika kukatakan kepada mereka: aku } \\
\text { temanmu }\end{array}$ & 6 & when I say to them, I am your friend & 9 \\
\hline beberapa anak berlari ketakutan & 4 & some of the children run away in fear & 8 \\
\hline yang lain tiba melempari batu & 5 & while other throw stones & 4 \\
\hline II & & II & \\
\hline aku menangis di bawah trembesi & 5 & I cry beneath a shade tree & 6 \\
\hline $\begin{array}{c}\text { di atas dahan kudengar seekor burung } \\
\text { bernyanyi }\end{array}$ & 7 & above, I hear a bird sing & 6 \\
\hline anak-anak berkata: lucu benar orang gila itu & 8 & $\begin{array}{l}\text { the children say: that crazy man is really } \\
\text { funny }\end{array}$ & 9 \\
\hline sehari muput menangis tersedu-sedu & 5 & all he does is cry and sob the whole day & 10 \\
\hline orang-orang yang lewat di jalan & 6 & people passing by on the street & 6 \\
\hline berkata pelan: orang itu sudah jadi gila & 7 & mutter: that man is crazy & 5 \\
\hline sebab terlalu berat menafsir makna dunia & 6 & $\begin{array}{l}\text { from trying too hard to understand the } \\
\text { meaning of the world }\end{array}$ & 11 \\
\hline III & & III & \\
\hline sekarang kususuri saja sepanjang jalan raya & 6 & now I wander along the size of the road & 9 \\
\hline sambil bernyanyi: aku bukan orang gila & 6 & while singing: I am not crazy & 6 \\
\hline IV & & IV & \\
\hline kupukul tong sampah dan tiang listrik & 6 & I bang a garbage can, electric poles & 7 \\
\hline kunyanyikan lagu tentang lapar yang menarik & 6 & I sing pop songs about hunger & 6 \\
\hline kalau hari ini aku tak makan lagi & 7 & if today I don't eat again & 7 \\
\hline jadi genap sudah berpuasa dalam tiga hari & 7 & it will be three straight days I've fasted & 9 \\
\hline tapi pasar sudah sepi, sayang sekali & 6 & but the market is quiet, which is too bad & 9 \\
\hline tak ada lagi yang memberikan nasi & 6 & no one is there to offer me rice & 8 \\
\hline ke mana aku mesti pergi, ke mana lagi & 8 & $\begin{array}{l}\text { where is it that I must go, where must I go } \\
\text { now }\end{array}$ & 12 \\
\hline $\mathbf{V}$ & & $\mathbf{V}$ & \\
\hline orang itu sudah lama gila, kata mereka & 7 & $\begin{array}{l}\text { that man's been crazy for quite a while, they } \\
\text { say }\end{array}$ & 11 \\
\hline tapi hari ini begitu pucat nampaknya & 6 & but today he seems particularly pale & 6 \\
\hline apa kiranya yang telah terjadi padanya & 6 & what could have happened to him & 6 \\
\hline aku katakan pada mereka: aku tidak gila! & 7 & I say to them: I am not crazy! & 8 \\
\hline aku orang lapar, saudara. & 4 & I am hungry, my friend & 5 \\
\hline VI & & VI & \\
\hline
\end{tabular}


orang kota semua telah mengada-ada, aduhai
menuduhku seorang yang sudah gila
aku toh cuma menangis tanpa alasan
tertawa-tawa sepanjang jalan
dan lewat jendela, tergeleng kepala mereka:
kurus benar sejak ia jadi gila.

From the table above we can see that in general the total of words in the target poem is greater than the total of words in the source poem. Only in the first stanza second line, the second stanza third line, the fourth stanza second line 4 , and the sixth stanza second line, the total of words in the target poem is less than the total of words in the source poem. This is due to the use of words in the target language and the effect of structure on the target language.

Lavafere (1975) in his theory said that the use of literal translation strategies would not be able to move the original meaning in source language, because phrases and sentence structures tend to be different from target language. In fact, the translation of the poem Sajak Orang Gila with this strategy generally worked well. Most of the meaning in the source poem is conveyed in the target poem.

However, in the translation of the poem there are several stanzas that have a meaning incompatible at the word level. The discrepancies found include:

a. In the source poem, in the stanza 1 first line is written aku bukan orang gila, saudara, and in the stanza 10 second line written aku orang lapar, saudara, this word saudara in both lines are translated into English with my friend. Whereas the word my friend has a meaning that is far different from your word in the source poem, saudara. This is due to differences in physical or interpersonal perspectives in interpersonal and physical perspectives between the source language and the target language. In Indonesian, the word saudara is also a form of greeting to others. Actually, it is appropriate if the word saudara is translated with brother, because the word brother or bro is also a form of greeting to others. But this was not done by the translator, perhaps because the translator saw that in the next stanza, the second stanza first lines of the poem is written ketika kukatakan pada mereka, aku temanmu or in English when I say to them, I am your friend. That why the translator translated the word saudara into my friend.

b. In the third stanza first line of the source poem is written aku menangis di bawah trembesi. Trembesi is a large tree plant whose leaves are very shady, with a height of up to 20 meters. This plant is often found in tropical forest areas in Indonesia. Because the western country is not a tropical region, these plants are unknown, so they do not have a specific term for these plants. Therefore, the statement aku menangis di bawah trembesi translated into I cry beneath a shade tree, only said to take shelter under a shady tree. In other words, the target language does not have a subordinate element (hyponym), namely trembesi, so only use words that are superordinate of trembesi, ie shady trees.

c. In the stanza 10 first line of the source poem is written orang kota semua telah mengada-ada, aduhai. The term aduhai may be appropriate if translated with how wonderful. But the translator does not use the term, but is translated with utterly fantastic. Perhaps this is 
due to differences in expressive meaning. The word aduhai in source language and how wonderful in target language have the same proposition meanings but differ in expressive meaning. The use of the word utterly fantastic is considered more expressive than how wonderful. Therefore, translators prefer use the word utterly fantastic, to translate the word aduhai.

\section{REFERENCES}

Anggana, R. L. (2012). Textual Elements and Translation Methods of Toeti Heraty's Poems Translated by Ulrich Kratz. Tesis. Semarang: Udinus. Retrieved from: http://eprints.dinus.ac.id/5988/1/ful 1_thesis.pdf

Baker, M. (1992). In Other Words. London: Routledge.

Bassnett, S. (2002). Translation Studies. London: Routledge.

Catford, J. C. (1974). A Linguistic Theory of Translation. London: Oxford University Press.

Damono, S. J. (1961). Sajak Orang Gila. Sastra No. 1 Th. 7, November 1961.

Damono, S. D., \& McGlynn. J. H. (1988). Suddenly the night: The poetry of Sapardi Djoko Damono. Jakarta: Lontara Foundation.

Frost, W. (1969). Dryden and the Art of Translation. Connecticut: Yale University Press.

Kosasih, E. (2008). Dasar-Dasar Keterampilan Bersastra. Bandung: Yrama Widya.

Lefevere, A. (1975). Translating poetry: Seven strategies and a blueprint

\section{CONCLUSION}

The translation of the Sajak Orang Gila into English Ballad of a Crazy Man has been done well by translator. Although the literal translation strategy theoretically is said to be inappropriate to translate poem, in fact the translation of the poem Sajak Orang Gila is able to present poem which is poetic and interesting to read. Although there are some discrepancies at the word level, it does not really affect the content of the poem. In general, the meaning of the source poem conveyed to the target poem.

(Approaches to translation studies). Assen: Van Gorcum.

Lazim, H. G. (n.d.). Poetry Translation. Retrieved from: https://www.translationdirectory.co m/articles/article1362.php

Nababan, M. R. (2003). Teori Menerjemah Bahasa Inggris. Yogyakarta: Pustaka Pelajar

Newmark, P. (1988). A Textbook of Translation. New York: Prentice Hall

Prasetyo, A. (2016). Penerapan Metode Penerjemahan Interpretasi Puisi oleh Susan Bassnett. LINGUISTIK ID. Retrieved from: https://www.linguistikid.com/2016/ 07/metode-penerjemahaninterpretasi-puisi-bassnett.html

Ramli, Ramli. (2019). Lexical Distortion: A Study on Indonesian-English Translation. ETERNAL (English, Teaching, Learning and Research Journal), 5(1), 11-20. Retrieved from

https://doi.org/10.24252/Eternal.V5 $\underline{1.2019 . \mathrm{A} 2}$

Sari, P. (2015). Penggunaan Metafora dalam Puisi William Wordsworth. DIALEKTIKA: Jurnal Ilmiah Pendidikan Bahasa, Sastra, Dan 
Matematika, 1(2), 115-128. Venuti, L. (2004). The Translation Studies. Retrieved from http://journal.fkipLondon: Routledge.

unilaki.ac.id/index.php/dia/article/v iew/11 